\title{
Klaus - an exceptional winter storm over northern Iberia and southern France
}

Article

Published Version

Liberato, M. L. R., Pinto, J. G., Trigo, I. F. and Trigo, R. M. (2011) Klaus - an exceptional winter storm over northern Iberia and southern France. Weather, 66 (12). pp. 330-334. ISSN 1477-8696 doi: https://doi.org/10.1002/wea.755 Available at https://centaur.reading.ac.uk/32765/

It is advisable to refer to the publisher's version if you intend to cite from the work. See Guidance on citing.

Published version at: http://dx.doi.org/10.1002/wea.755

To link to this article DOI: http://dx.doi.org/10.1002/wea.755

Publisher: Wiley

All outputs in CentAUR are protected by Intellectual Property Rights law, including copyright law. Copyright and IPR is retained by the creators or other copyright holders. Terms and conditions for use of this material are defined in the End User Agreement.

\section{www.reading.ac.uk/centaur}

\section{CentAUR}

Central Archive at the University of Reading

Reading's research outputs online 


\section{Klaus - an exceptional winter storm over northern Iberia and southern France}

\section{Margarida L. R. Liberato $^{1,2}$, Joaquim G. Pinto $^{3}$, Isabel F. Trigo ${ }^{2,4}$ and Ricardo M. Trigo ${ }^{2,5}$ \\ 'School of Sciences and Technology, UTAD, Portugal \\ ${ }^{2}$ CGUL-IDL, University of Lisbon, \\ Portugal \\ ${ }^{3}$ Institute for Geophysics and Meteorology, University of Cologne, Germany \\ ${ }^{4}$ Institute of Meteorology, Lisbon, Portugal \\ ${ }^{5}$ Engineering Department, University Lusófona, Lisbon, Portugal}

\section{Introduction}

Extratropical cyclones are one of the most important features of the mid-latitude climate and represent a primary mechanism for poleward transport of heat and moisture. They typically develop as a result of the interaction between warm subtropical air and cold polar air masses over the mid-latitudes of both hemispheres. Over the North Atlantic (NA) extratropical cyclones (depressions) often undergo a strong intensification phase over the ocean, move eastwards and reach Europe where they are one of the main factors influencing local weather. Intense depressions are often associated with very strong winds and large precipitation totals (Raible et al., 2007) and are among the most severe natural hazards affecting Europe.

Such systems appear less often over southern Europe (Trigo, 2006; Pinto et al., 2009), but do occur sometimes when the jet stream pattern allows, and this paper describes an extreme example: storm Klaus (see Box 1 for storm names). On 21 January 2009 the jet stream extended across the NA Basin into Western Europe, and Klaus formed and moved, broadly, eastwards at a relatively low latitude (between $35^{\circ} \mathrm{N}$ and $45^{\circ} \mathrm{N}$ ) on the edge

\section{Box 1. Naming of pressure systems}

Since 1954, the Institute of Meteorology of the Freie Universität Berlin has named all pressure systems in Central Europe, with lows given female names and highs given male names. In 1998, following a discrimination discussion, names began to be assigned by giving the lows male names and the highs female names in odd years, and vice versa in even years. Since 2002, alphabetical lists are made from names suggested by the public. Source: http://www.met.fu-berlin.de/adopt-a-vortex/historie/ identified in most climatological studies (e.g. Hoskins and Hodges, 2002; Pinto et al., 2005; Trigo, 2006, and Figure 1). It swept by northern Iberia and southern France late on 23 January and during 24 January, and was considered the most since the devastating storm Martin in late December 1999 (Ulbrich et al., 2001).

\section{Data}

Mean sea-level pressure (MSLP) charts from the European Centre for Medium-Range damaging wind storm to affect these areas
Weather Forecasts (ECMWF) Interim Reanalyses (ERA-Int) (Dee and Uppala, 2009) are considered for the NA European sector $\left(85^{\circ} \mathrm{W}\right.$ to $\left.50^{\circ} \mathrm{E} ; 20-70^{\circ} \mathrm{N}\right)$ for January 2009 , at the full temporal (six-hourly) and spatial $\left(0.75^{\circ}\right.$ regular horizontal grid) resolutions available. Additionally, 500mbar geopotential height fields and $250 \mathrm{mbar}$ wind and divergence are considered so as to analyse largescale conditions associated with the development of the storm. Maximum gust speeds observed at 75 stations located in northern Spain and southern France were retrieved from preliminary reports published

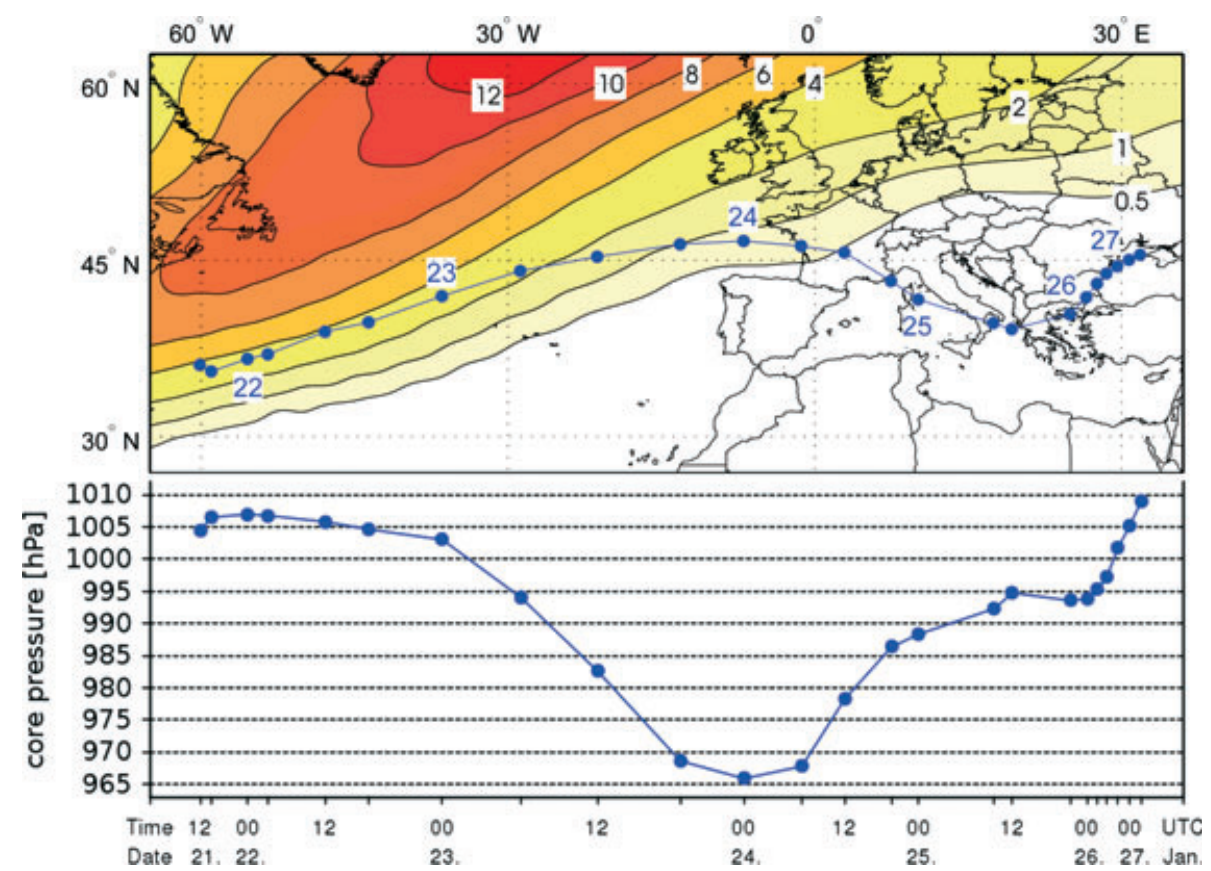

Figure 1. Surface track of Klaus. The position of the storm at six-hourly intervals is marked with a filled circle. The corresponding core MSLP data are shown in the bottom panel for the period 1200 UTC 21 January 2009 to 0600 UTC 27 January 2009. Contour lines represent the track density of the major (extreme) cyclones (cyclone days/winter) over the NA European sector (adapted from Pinto et al., 2009, their Fig. 4). 
by the corresponding Spanish ${ }^{1}$ and French ${ }^{2}$ Meteorological services. UK Met Office weather charts were analysed, and infrared channel METEOSAT satellite images provided by the Deutsch Wetterdienstweather service (DWD) were used for the analysis of cloud patterns and mid-level moisture transport.

\section{Results}

\section{General description and impacts}

Using an automatic cyclone tracking method (Murray and Simmonds, 1991; Pinto et al., 2005), Klaus was first identified on 21 January 2009 as a small wave perturbation. The developing wave was embedded in the strong westerly flow and experienced a sharp intensification on 23 January around $21^{\circ} \mathrm{W}$; it moved rapidly towards the Bay of Biscay, where it deepened further (Figures 1 and 2). At this stage severe storm force gusts of up to $55 \mathrm{~ms}^{-1}(107 \mathrm{kn})$ were measured at low-level stations, accompanied by heavy rain and attendant flooding, whilst snow fell across the Cantabrian Mountains and the Pyrenees. The strongest winds (and heaviest rain) were concentrated around the Pyrenees (Figure 3). Previous long-term records of wind speed were surpassed in several French cities as well as at other country stations. However, the impacts of the storm were felt over a wider area, including important urban sites in Spain (Santander, Bilbao, Barcelona) and France (Bordeaux, Narbonne, Perpignan) (Figure 4). The Spanish Oceanographic Institute (IEO) registered a new record of wave height within Spanish sea waters. According to data available from a buoy 22 miles north of Santander, two peak waves of $26.13 \mathrm{~m}$ and $24.65 \mathrm{~m}$ were registered between 0600 and 0700 on the morning of 24 January. ${ }^{3}$ This magnitude of wave height was not foreseen when the buoy was designed and deployed, and the buoy drifted away (albeit still transmitting data) after the anchor cable broke. Thus, from this time on, the buoy data does not correspond exactly to the same location but from fairly close proximity. The readings from it show a peak of significant wave height during the morning of 24 January: 14.88m (Figure 5), the highest observed for this short-lived buoy (deployed in September 2007) and coincident with the lowest pressure observed (980mbar). In fact, this wave height is not

\footnotetext{
'Spanish weather service report: http://www. aemet.es/documentos/es/noticias/2009/03/ ciclogenesisexplosiva_2325_01_2009_corr_ V3.pdf (accessed on 18 November 2010).

${ }^{2}$ Meteofrance report: http://france.meteofrance. com/jsp/site/Portal.jsp?page_id=11330\&page_ $i d=10833$ (accessed on 18 November 2010).

${ }^{3}$ Press release from IOE; http://www.ieo. es/prensa/NpOla26m.pdf (accessed on 18 November 2010).
}

(a)

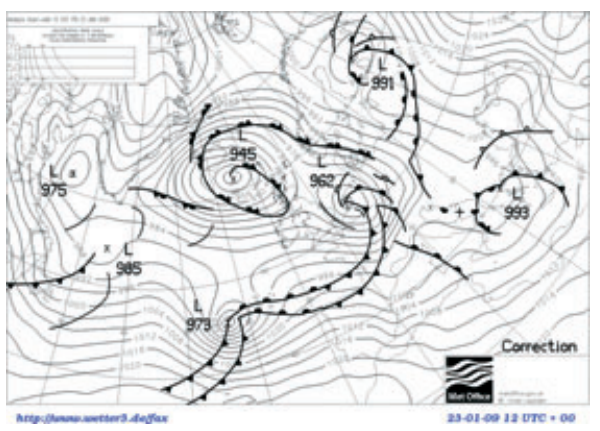

(c)

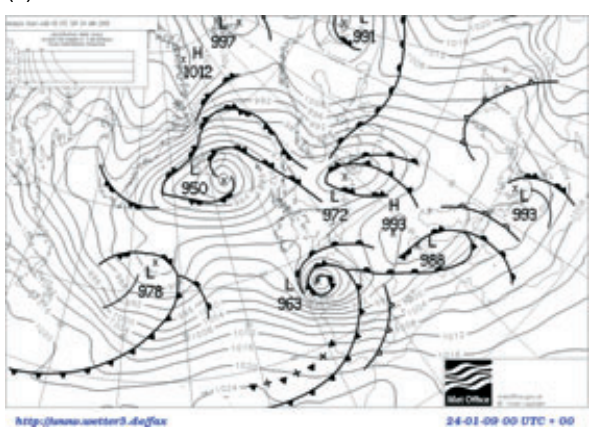

(e)

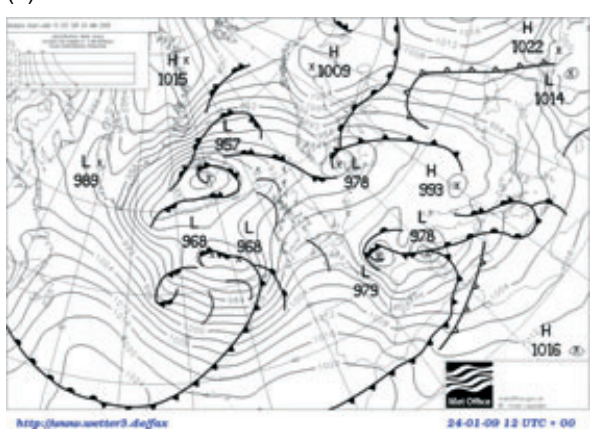

(b)

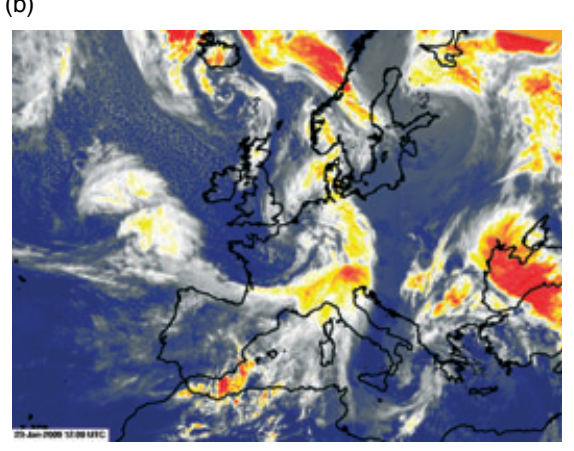

(d)

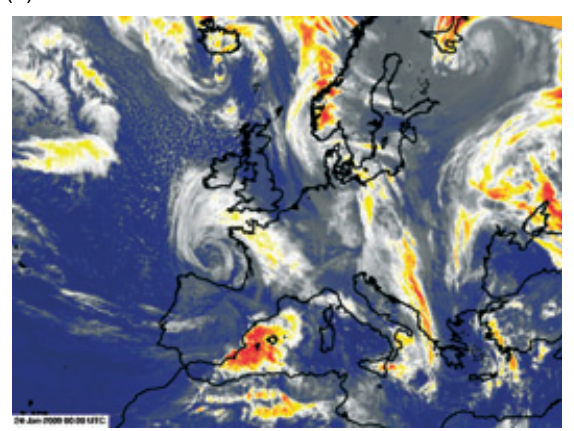

(f)

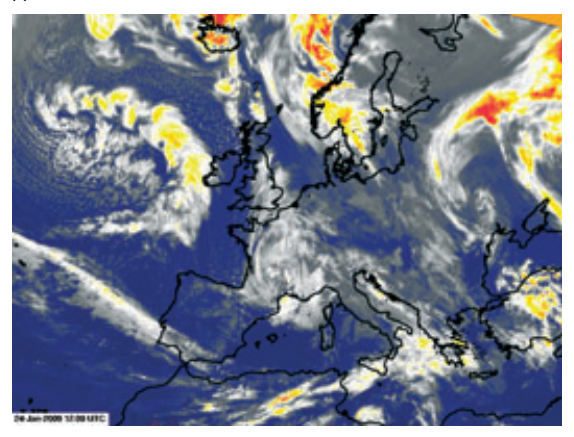

Figure 2. UK Met Office surface weather charts and infrared channel METEOSAT satellite images provided by the DWD for, (a) and (b) 1200 UTC on 23 January 2009; (c) and (d) 0000 UTC on 24 January 2009 and (e) and (f) 1200 UTC on 24 January 2009. (Crown copyright, the Met Office.)

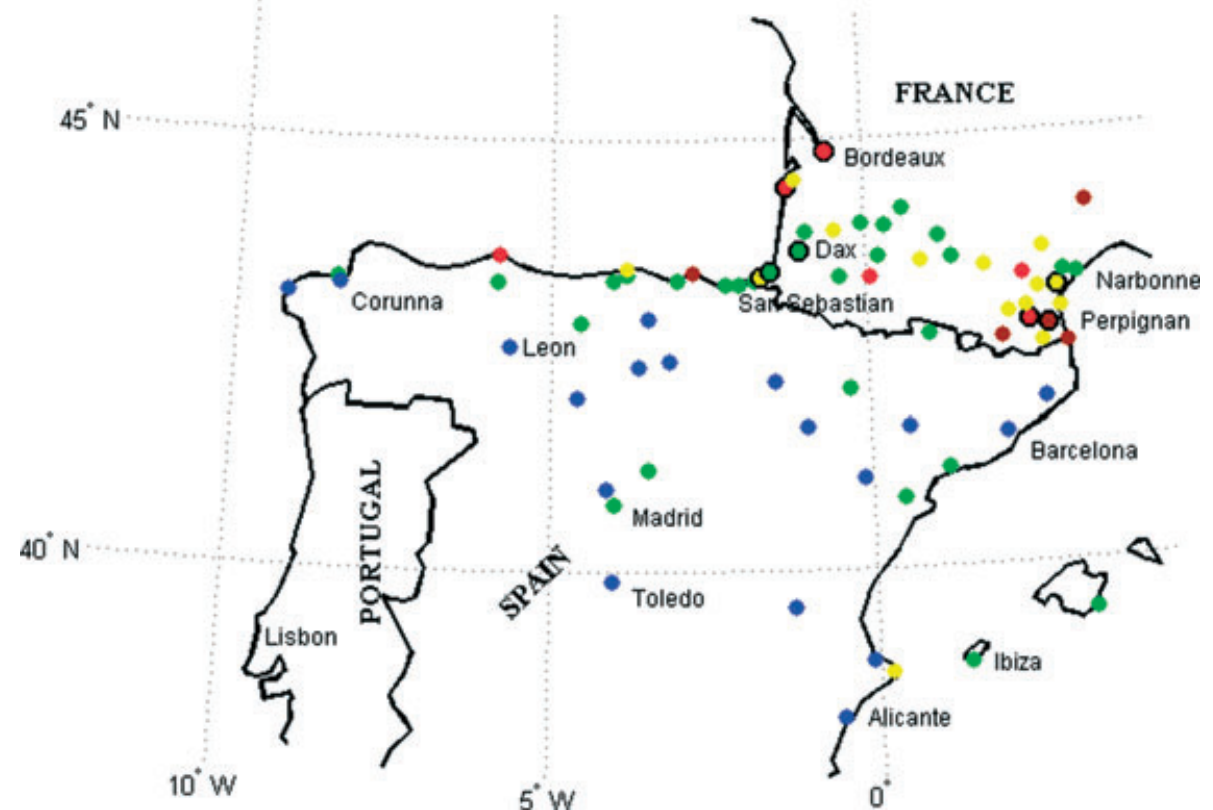

Figure 3. Maximum gusts measured at Spanish and French meteorological stations. Blue: 28-33ms $\mathrm{m}^{-1}$ (54-65kn); green: 33-39ms $\mathrm{m}^{-1}$ (65-76kn); yellow: 39-44ms $\mathrm{m}^{-1}$ (76-86kn); red: 44-50ms (86-97kn) and brown $>50 \mathrm{~ms}^{-1}$. A black circumference is included around those stations where previous long-term records of wind speed were surpassed. 


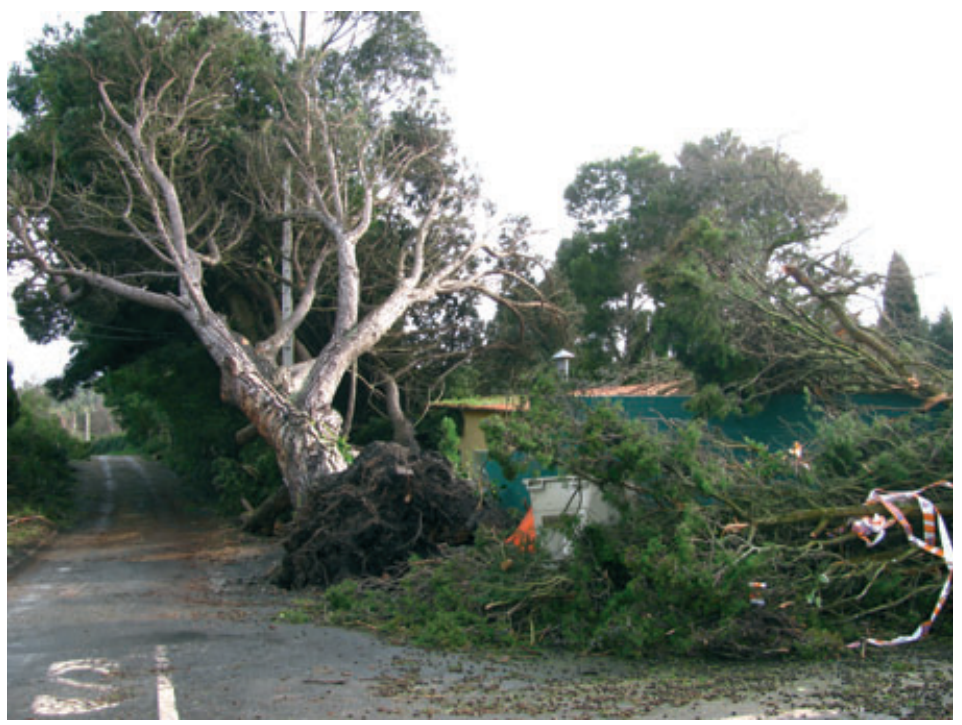

Figure 4. Example of damage associated with Klaus, near Corunna, northern Spain. (Photograph courtesy of Pablo Herrero Isasi.)

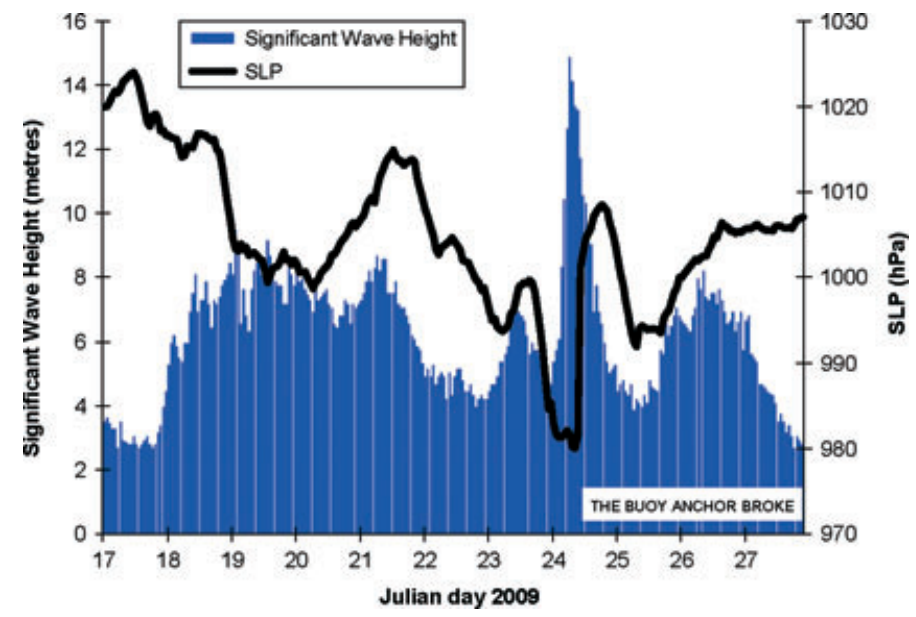

Figure 5. Hourly averages of significant wave height and sea-level pressure between 17 and 27 January 2009 from a buoy north of Santander. Missing readings (c. 10\%) were linearly interpolated. Note that data from 24 to 27 January are from the drifting buoy (see text for details).

only the highest ever registered in this area but also within Spanish waters.

On 24 January the storm moved towards Italy and there were now two pressure minima: one over southern France and another over the Gulf of Genoa (Figure 2(e)). The latter (hereafter named Klaus II) developed at the occlusion point of Klaus and was apparent over the Gulf of Lion by 0600 UTC that day. From 25 January onwards, the cyclone track (Figure 1) follows Klaus II over the Adriatic Sea towards the Aegean and Black Seas, whilst the original system decays over southern France/northern Italy.

The French meteorological surveillance warning service issued (for the first time since 2001) the highest level of wind warnings for nine regions in the southwest of the country (Météo-France report). Unfortunately these were only issued at the height of the storm, not giving sufficient time to people and authorities to be taneously (as happened with Klaus). airports closed. The reinsurance industry ranked the effects of Klaus as the most costly event of 2009 with over US\$6 billion in losses being reported, mainly from France and Spain (Aon-Benfield, 2010). According to various insurers, insured losses were US\$2.3 billion in France and US\$1 billion in Spain after at least 715000 claims were filed. It was described as the most damaging wind storm affecting northern Iberia, southern France and the western Mediterranean since storm Martin in December 1999 that killed 88 people and uprooted millions of trees (Ulbrich et al., 2001).

\section{Large-scale conditions associated with the explosive development}

The occurrence of intense storms over the NA Ocean and Europe is favoured by a strong north-south temperature gradient in the low-to-mid troposphere, which contributes to stronger than average winds in the mid-to-upper troposphere across the region (e.g. Fink et al., 2009). As pointed out by several authors (e.g. Uccellini and Johnson, 1979), the development of intense depressions occurs when the location of the initial perturbation with respect to the upper-level jet favours its amplification within enhanced low-level baroclinicity (Box 2). The incipient wave from which Klaus developed was some $800 \mathrm{~km}$ to the eastnortheast of Bermuda on 21 January within an area of enhanced meridional temperature $\left(\theta_{\mathrm{e}}\right.$, used as an indicator of the combined effect of latent and sensible heat) and developed downstream near the Azores (Figure 6(a)). The upper-level flow over the western NA was anomalously strong and oriented in a southwest-northeast direction (Figure 6(b)).

The cyclone path followed very closely the region characterized by the largest equivalent potential temperature gradient, within the transition between subtropical and polar air masses (Figure 6(c)). The comparison of the cyclone trajectory, $500 \mathrm{mbar}$ geopotential height and $\theta_{\mathrm{e}}$ at $850 \mathrm{mbar}$ reveals a maximum of latent and sensible heat availability in the lower troposphere immediately downstream of the upper and surface disturbances (Pinto et al., 2009). Thus, the lower troposphere $\theta_{\mathrm{e}}$ and the vertical crosssections of relative humidity indicate that

\section{Box 2. Cyclone development and jet streaks}

The links between cyclone development and jet streaks - regions with maximum upper air wind speed - have been studied for many years (e.g. Uccellini and Johnson, 1979; Reed and Albright, 1986). Extratropical cyclones typically intensify when they cross the polar jet stream, but this intensification is sensitive to the relative position between jet and cyclone. The intensification is particularly enhanced if the system is located at the south of the jet entrance or north of the jet exit (for the Northern Hemisphere). This effect is induced by ageostrophic winds associated with the wind speed acceleration and isobaric confluence at the entrance, and wind speed reduction and isobaric diffluence at the exit. Several jet streaks may contribute to the cyclone development simul- 
the development was fed by very warm and moist air (Figure 6(e)). This assessment is supported by the meridional relative humidity vertical profile for 1200 UTC on 23 January from $25^{\circ} \mathrm{W}$ to $21^{\circ} \mathrm{W}$ (Figure $6(\mathrm{f})$ ), which shows high relative humidity $(>90 \%)$ in the warm air mass, embedded in the jet stream, moving from the southwest and suggesting its contribution to the baroclinic development.

To evaluate the source of the air mass and moisture associated with Klaus, backward trajectories were started from the location of the storm for various time steps. Results (not shown) indicate that many of the trajectories arrived from the subtropics and included a considerable amount of moisture. This assessment is in agreement with work by Knippertz and Wernli (2010: their Figure 4) who suggest Klaus as a possible example of 'tropical moisture export' (TME) influence on rapid extratropical cyclogenesis. Their analysis from 19 January to 24 January showed that the development of Klaus was embedded in a massive TME event which originated over the entire central and western tropical Atlantic and then converged into the genesis region of the cyclone.

An important factor in the development is the relative position of the storm and the upper-level jet. The surface depression first appeared to the south of the jet, then it was steered by the upper-level flow northeastward over the central NA, north of the Azores, where the explosive cyclogenesis began. During its maturing stage, rates of deepening exceeded $37 \mathrm{mbar}$ per 24 hours (1003.0-965.9mbar during 23 January), which
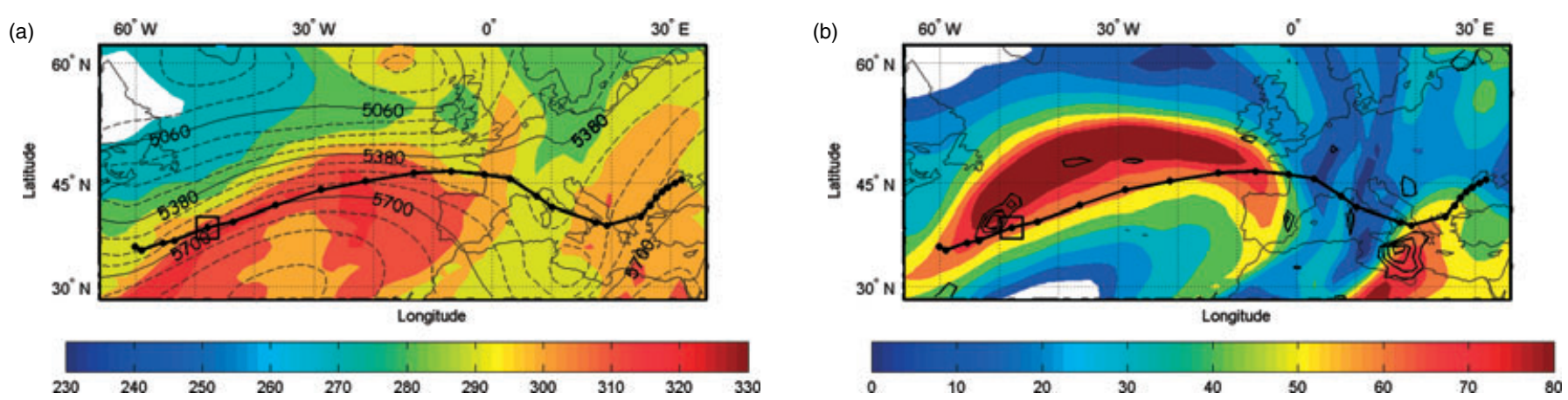

(c)

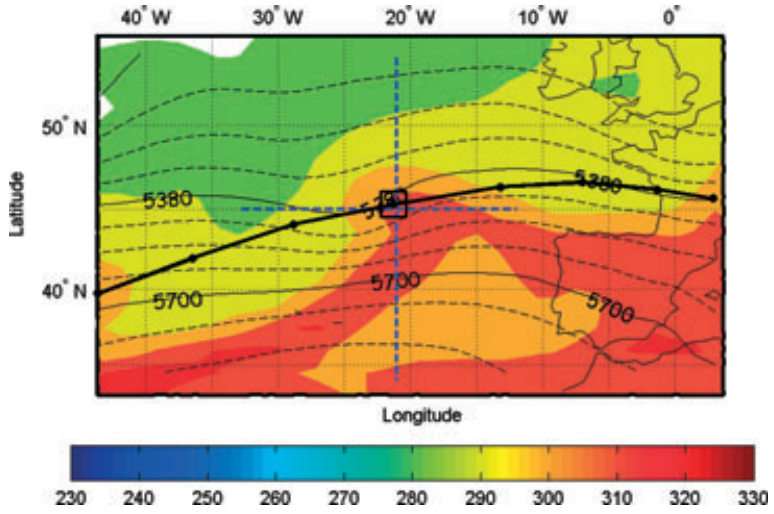

(d)
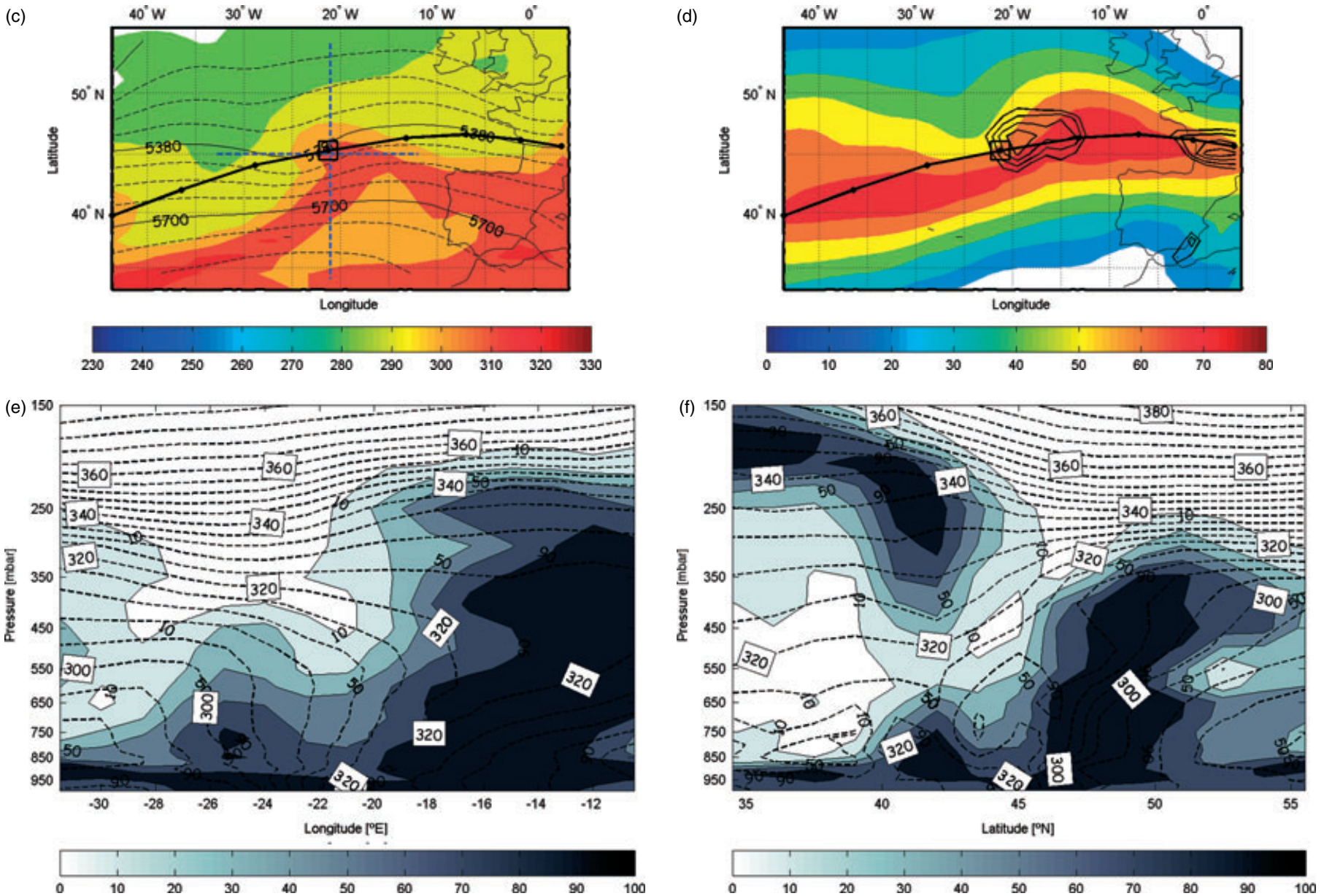

Figure 6. Large-scale conditions associated with the development of storm Klaus. (a) $\theta_{\mathrm{e}}$ field at $850 \mathrm{mbar}$ (shaded: temperature in kelvins) and the 500 mbar geopotential height (contours every $80 \mathrm{gpm}$ ) for 1200 UTC on 22 January. (b) wind speed (shaded: ms ${ }^{-1}$ ) and divergence (contours every $10 \times 10^{-6} \mathrm{~s}^{-1}$, delimiting areas above $30 \times 10^{-6} \mathrm{~s}^{-1}$ ) at the $250 \mathrm{mbar}$ level for 1200 UTC on 22 January. (c) as (a) but for 1200 uTC on 23 January. The dashed lines show the location of the vertical sections. (d) As (b) but for 1200 UTC on 23 January. (e) west-east oriented sections of the relative

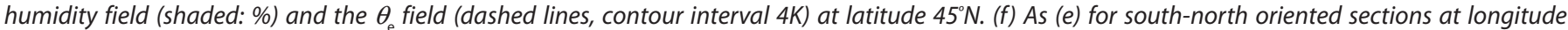
$21^{\circ} \mathrm{W}$. Cyclone track is displayed in black and position at corresponding time is marked with a square. 
after being geostrophically adjusted to the reference latitude of $60^{\circ} \mathrm{N}$ (Trigo, 2006), is equivalent to $44 \mathrm{mbar}$ per 24 hours, implying an exceptional event with 'bombcharacteristics'. At 0600 UTC on 23 January the depression was positioned at the rear of the nearly zonal jet and was moving towards a region of stronger winds and higher divergence values $\left(>30 \times 10^{-6} \mathrm{~s}^{-1}\right)$. During the next six hours the jet shifted southwards and became further elongated, developing two velocity maxima with the surface cyclone located in between (Figure 6(d)). During this phase Klaus crossed the jet to its poleward side, and its rapid development began as it exited the maximum velocity region. While such 'bombs' are not uncommon over the NA Basin (Sanders, 1986; Trigo, 2006), they are very rare this far south (Pinto et al., 2009). The intensification of Klaus was also probably supported by the split jet streak and associated strong upper-air divergence between the two jets. Similar cases where split jets and enhanced upper-air divergence played an important role in storm development have been reported previously - for example, Lothar (Ulbrich et al., 2001) and Kyrill (Fink et al., 2009).

\section{Summary and conclusion}

We have presented a description of the synoptic evolution, impacts and the most relevant large-scale features associated with storm Klaus, the costliest weather hazard event in the world during 2009 with over US\$6.0 billion in total losses reported (AonBenfield, 2010). The system underwent a rather typical mid-latitude explosive development, closely associated with the crossing of the polar jet, but this development occurred at an unusually low latitude, on the southern boundary of the NA main storm track climatological 'normal' envelope, due to the southerly displacement of the polar jet stream. Klaus underwent an explosive development with 'bomb' characteristics between the Azores and the Iberian Peninsula, with a deepening rate of $37 \mathrm{mbar}$ in 24 hours, unusually high for these latitudes. The development of Klaus was also apparently supported by an extraordinary tropical moisture export over the entire

\footnotetext{
${ }^{4}$ 'Bombs' are rapidly deepening extratropical surface cyclones with a pressure fall in the depression centre at sea level of at least $\left(24^{*} \sin \phi / \sin 60^{\circ}\right) \mathrm{mbar}$ in 24 hours. This corresponds to $24 \mathrm{mbar}$ in 24 hours at latitude $60^{\circ} \mathrm{N}$. The geostrophically-equivalent rate at $45^{\circ} \mathrm{N}$ is $19.6 \mathrm{mbar}$ in 24 hours.
}

central and western tropical Atlantic converging into its genesis region, and then moving along with the storm towards Europe.

Unlike most intense winter cyclone events affecting Iberia and southern France, which are generally associated with moderateto-strong precipitation, Klaus was primarily characterized by strong winds, and longterm records of wind speed were surpassed at several stations. Such storms are an increasingly important research topic: Martin, in December 1999, had a similar development, followed a very similar path and produced even stronger impacts and the recent storm Xynthia (28 February 2010) intensified strongly over the Bay of Biscay in association with a strong jet over southwestern Europe, even though it followed a northeastward track thereafter.

In this paper, we have identified some of the mechanisms that were ultimately responsible for the unusual path and strength of Klaus and its associated impacts, but this peculiar system deserves a more indepth study to seek to quantify the contribution from all the physical mechanisms involved (e.g. latent and sensible heats, energy transfer between planetary and synoptic scale atmospheric waves etc.) in order to improve both diagnosis studies and the accuracy of forecasts and warnings of severe weather.

\section{Acknowledgements}

This work was partially supported by the FCT (Portugal) through project ENAC (PTDC/AACCLI/103567/2008). MLRL is also supported by a postdoctoral FCT grant (SFRH/BPD/ 45080/2008). The authors thank DWD and the UK Met Office for satellite images and synoptic data/charts. Buoy data was kindly provided by the Spanish Oceanographic Institute (IEO). We also thank Pablo Herrero Isasi for providing the picture displayed in Figure 4, and Patrick Ludwig (Univ. Cologne) for help with Figure 1. We thank Andreas H. Fink (Univ. Cologne), Andreas Reiner and Richard Dixon (both AON-Benfield) for fruitful discussions. The authors are also indebted to two anonymous reviewers for their detailed comments and suggestions which helped to improve this paper.

\section{References}

Aon-Benfield. 2010. Annual global climate and catastrophe report IF 2009. http://www. aon.com/attachments/reinsurance/200912 ab_if_impact_forecasting_2009_report.pdf [accessed 18 November 2010].
Dee D, Uppala S. 2009. Variational Bias Correction in ERA-Interim. ECMWF Newsletter, No. 119. ECMWF: Reading, UK, pp 21-29.

Fink AH, Brücher T, Ermert E, Krüger A, Pinto JG. 2009. The European storm Kyrill in January 2007: synoptic evolution, meteorological impacts and some considerations with respect to climate change. Nat. Hazards Earth Syst. Sci. 9: 405-423.

Hoskins BJ, Hodges KI. 2002. New perspectives on the northern hemisphere winter storm tracks. J. Atmos. Sci. 59: 1041-1061.

Knippertz P, Wernli H. 2010. A lagrangian climatology of tropical moisture exports to the Northern Hemispheric extratropics. J. Climate 23: 987-1003.

Murray RJ, Simmonds I. 1991. A numerical scheme for tracking cyclone centres from digital data. Part I: development and operation of the scheme. Aust. Meteorol. Mag. 39: 155-166.

Pinto JG, SpangehI T, Ulbrich U, Speth P. 2005. Sensitivities of a cyclone detection and tracking algorithm: individual tracks and climatology. Meteorol. Z. 14: 823-838.

Pinto JG, Zacharias S, Fink AH,

Leckebusch GC, Ulbrich U. 2009. Factors contributing to the development of extreme North Atlantic cyclones and their relationship with the NAO. Clim. Dyn. 32: 711-737.

Raible CC. 2007. On the relation between extremes of midlatitude cyclones and the atmospheric circulation using ERA40. Geophys. Res. Lett. 34: L07703. doi:10.1029/2006GL029084

Reed RJ, Albright MD. 1986. A case study of explosive cyclogenesis in the Eastern Pacific. Mon. Weather Rev. 114: 2297-2319.

Sanders F. 1986. Explosive cyclogenesis in the West-Central North Atlantic Ocean 1981-84. Part I: composite structure and mean behavior. Mon. Weather Rev. 114: 1781-1794.

Trigo IF. 2006. Climatology and interannual variability of storm-tracks in the EuroAtlantic sector: a comparison between ERA-40 and NCEP/NCAR reanalyses. Clim. Dyn. 26: 127-143.

Uccellini LW, Johnson D. 1979. The coupling of upper and lower tropospheric jet streaks and implication for the development of severe convective storms. Mon. Weather Rev. 107: 682-703.

Ulbrich U, Fink AH, Klawa M, Pinto JG. 2001. Three extreme storms over Europe in December 1999. Weather 56: 70-80.

Correspondence to: M. L. R. Liberato, School of Sciences and Technology, University of Trás-os-Montes e Alto Douro, Quinta de Prados, Apt. 1013,

5001-801 Vila Real,

Portugal

mlr@utad.pt

(c) Royal Meteorological Society, 2011

DOI: 10.1002/wea.755 